\title{
Planning tourist infrastructures to regenerate marginalised territories: the study case of North Sardinia, Italy
}

\author{
Ludovica Sechi, Rossella Moscarelli ${ }^{*}$ and Paolo Pileri
}

\begin{abstract}
European marginalised areas are affected by an alarming rate of abandonment and depopulation. Thus, they are therefore object of specific European policies aiming to their reactivation. Official guidelines, both European and Italian, indicate sustainable tourism as one of the main triggers able to activate positive processes. This research experiments a suggestion in a case study, the North of Sardinia. The coastal areas of Sardinia are popular tourist destinations, particularly in the North with the famous Costa Smeralda. Therefore, it is worthy to imagine a way to allow them to discover the inner territories of the region too.
\end{abstract}

Keywords: Territorial marginalisation, European cohesion policies, Italian inner areas, Regeneration, Slow tourism

\section{Introduction}

It is possible to consider marginalisation as a process, driven by a combination of social, political and environmental factors (Brouwer et al. 1997) by which certain areas cease to be viable under an existing socio-economic structure. Marginalisation is an increasing phenomenon across Europe (Espon 2017a), affecting rural (Espon 2017b) and mountain (Nordregio 2004) areas especially. Key signs of de-anthropisation (Breman et al. 2010) highlight marginalisation conditions: population falling below the critical threshold and demographic ageing, due to dwindling employment and use of territorial capital. One key factor of this marginalisation is the demographic issue: by 2050, the population of Europe's urban regions is projected to increase by 24.1 million people and will provide homes to almost half of the EU-28 population. By contrast, the population of other regions is likely to fall by 7.9 million (Eurostat 2016). Such shrinkage is simultaneously a demographic and economic phenomenon and has to be interpreted as part of wider trends in European territorial restructuring, currently characterised by a significant regional development imbalance (Serbanica and Constantin 2017). A growing mismatch between the

\footnotetext{
*Correspondence: rossella.moscarelli@polimi.it
}

Politecnico di Milano, Milano, Italy supply and demand of services represents the general reason for such depopulation. Local living conditions and quality of life deteriorate, unemployment rises and skilled labour becomes scarce, causing migration to urban poles, which provide more services. Processes of marginalisation are also related to loss of identity and bonds with the territory, caused by the huge decrease of inhabitants (Turco 1984; Maciocco et al. 2011).

When addressing the issue of marginalisation, the general frame to take into account is the European Cohesion Policy. This is essentially a regional development policy with the aim to support all regions of the EU in reaching their full potential in terms of economic and social development. As Danson and De Souza $(2012,100)$ point out,

'the word cohesion stands as a substantiated nucleus of political thinking, where the issue of balanced levels of economic development and welfare aspects of society are addressed jointly. In particular, Article 2 of the Maastricht Treaty states the goals of the EU as incorporating the promotion of the harmonious and balanced economic development.'

In other words, Cohesion Policy has the role to stem the critical condition caused by the territorial imbalance, in terms of economic, political, social and cultural 


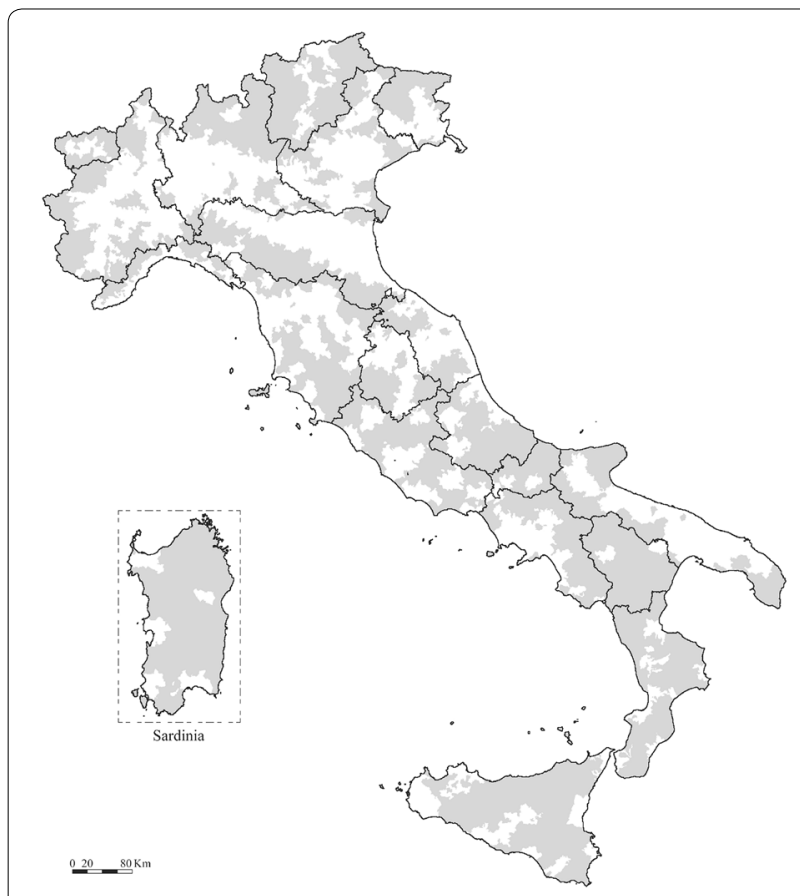

Fig. 1 Italian inner areas (in grey) (Source: Elaboration from data processed by UVAL (2014))

inequality, that contributes into generating phenomena of marginalisation.

As a direct consequence of the European Cohesion Policy in the 2014-2020 period (EC 2011), the Italian Public Investment Evaluation Unit (UVAL), reported to the Department for Development and Economic Cohesion of the Ministry for Economic Development, carried out the Strategy for Inner Areas. Inner areas are defined as territories substantially far from those centres offering essential services and are thus characterised by depopulation and decline (UVAL 2014; Barca 2009). From this definition, it appears that remoteness and level of accessibility to services, crucial to ensure a good quality of life to the citizen (such as education, mobility and healthcare) are the main criteria to identify inner areas. According to these criteria, inner areas have been mapped throughout the Italian territory (Fig. 1). They cover $60 \%$ of the National territory, hosting nearly 13,540 million people. Italian inner areas are located approximately in Alpine and Apennine territories and they are mainly, 84\%, formed by small municipalities, that means with less than 5000 inhabitants (Ifel 2015). Analysing demographic data (Anci and Ifel 2015), we can see how small Italian municipalities are suffering a demographic crisis: in the 1991-2016 period their population decreased by $6.3 \%$, while national population increased by $7 \%$.

The National Strategy for Italian inner areas proposes some guidelines for local development, experimenting, thanks both to the European and Italian funds, in 22 pilot areas in the Country (Lucatelli 2015). Thus, such phenomenon of marginalisation is not considered as irreversible (Domansky and Lung 2009), also regarding the re-population process (Bayona and Gil-Alonso 2012; Bender and Kanitscheider 2012; Pinilla et al. 2008). On the contrary, it should be seen as an opportunity to develop new strategies (Espon 2017a) able to regenerate this territory and to avoid the loss of natural and historical heritage (Di Biase 2013). Indeed, territorial capital is defined as

\section{'the stock of assets which form the basis for endoge- nous development in each city and region, as well as [...] the institutions, modes of decision-making and professional skills to make best use of those assets.' (OECD 2001, 13)}

In Italian inner areas, territorial capital consists of historic and artistic capital, agricultural, pastoral and forest systems, territorial protection, know-how and craftsmanship (UVAL 2014, 16). Taking care of these territorial assets is, at the same time, the final aim and the key element to trigger a strategy. On the one hand, only human activities and presence can maintain this huge capital. On the other hand, if well administrated, territorial capital becomes the resource to activate an alternative model of tourist development, with a consequent regeneration (Fratesi and Perucca 2017; Mazzola et al. 2018; Romão and Neuts 2017).

Sustainable tourism, seen as means of enhancing and exploiting the territorial capital, is proposed as a valid strategy to revitalise marginalised territories (UVAL 2014, 42). The direct experience of the territory is what sustainable tourism is based upon (Pine and Gilmore 1999). From this perspective, it can be considered a key factor in local development (Liu et al. 2017; Maretti and Salvatore 2012; Salvatore and Chiodo 2016), as demonstrated previously in the case of rural tourism, based on the natural and cultural assets (Garrod et al. 2005).

The main purpose of this study is to experiment and to apply one of the main guidelines suggested in the Italian Strategy for Inner Areas, which is the improvement of sustainable tourism to reactivate marginalised areas. Firstly, in the methodological section, the designing approach is explained. The case study is the methodology used to develop the study. The area is North Sardinia, in Italy, chosen due to the presence of many marginalised territories inland and of the mass tourism on the coasts. There is a pre-existing infrastructure, which allows flow from the coast to inner areas, that is the historical tourist train (called Trenino Verde) from Palau, located in the famous Costa Smeralda area, to Sassari. The strategy presented in this paper aims at combining the historical 
Table 1 Trends of increase/decrease of population in Sardinia, 1991-2016. Source: Elaboration from Istat data

\begin{tabular}{|c|c|c|c|c|c|c|}
\hline & & alities & Population 1991 & Popolation 2016 & Delta popula & n 2016-1991 \\
\hline & \# & n the total] & [inh.] & [inh.] & [inh.] & {$[\%]$} \\
\hline Municipalities (2016) & 377 & $100 \%$ & 1648248 & 1658138 & 9890 & $0,6 \%$ \\
\hline Coastal Municipalities (CM) & 71 & $19 \%$ & 822450 & 859695 & 37245 & $4,5 \%$ \\
\hline Inland Municipalities (IM) & 306 & $81 \%$ & 825798 & 798443 & -27355 & $-3,3 \%$ \\
\hline Municipalities classified as "Centers" & 59 & $16 \%$ & 777345 & 796277 & 18932 & $2,4 \%$ \\
\hline Municipalities classified as "Inner Areas" & 318 & $84 \%$ & 870903 & 861861 & -9042 & $-1,0 \%$ \\
\hline CM classified as "Inner Areas" & 54 & $76 \%$ & 301008 & 346623 & 45615 & $15,2 \%$ \\
\hline IM classified as "Inner Areas" & 264 & $86 \%$ & 569895 & 515238 & -54657 & $-9,6 \%$ \\
\hline Municipalities with pop $>5000$ inh. & 63 & $17 \%$ & 1088097 & 1139400 & 51303 & $4,7 \%$ \\
\hline Municipalities with pop $<5000$ inh. & 314 & $83 \%$ & 560151 & 518738 & -41413 & $-7,4 \%$ \\
\hline CM with pop $<5000$ inh. & 39 & $55 \%$ & 97208 & 103582 & 6374 & $6,6 \%$ \\
\hline IM with pop $<5000$ inh. & 275 & $90 \%$ & 462943 & 415156 & -47787 & $-10,3 \%$ \\
\hline
\end{tabular}

Highlighted the typology of municipality with a decrease of population. CM present an increase of population even when they are in the typology (inner areas or with pop $<5000$ inh.) with a general negative trend

railway with new cycle tourism paths. Offering a welldesigned alternative to coastal tourism is as a way to trigger a regeneration of Sardinian inner areas. Secondly, the project is described in the results section. The analysis of North Sardinia presents data on population, cultural and natural heritage and other infrastructures that interact with the Trenino Verde. In connection with this slow train line, three new cycle tourism paths are able to enter the territory more efficiently. Thirdly, in the discussion section, attention is drawn to what the case study is able to highlight. (1) Projects of sustainable tourism can revitalise marginalised areas if they represent an alternative to classical tourism. (2) Slow infrastructures, such as cycle tourism paths or historical railways, are excellent means by which one may enter the territory and enjoy its singularity. (3) The interaction between different infrastructures can increase travel possibilities, number of users and flexibility of the system. Finally, further development of this study is put forward.

\section{Methods}

\section{Using a case study: the reason for the choice}

The First methodological choice consists of experimenting, with a real case study, the idea of revitalising marginalised areas thanks to sustainable tourism. The case study, the North of Sardinia, was chosen because of an interesting dichotomy: the state of marginalisation of its inner areas and the strong tourist presence along the coasts.
According to the classification elaborated by Uval in 2014, Sardinia is one of the first Italian Regions for the percentage of Inner Areas: $84 \%$ of its territory is covered by Inner Areas. This data is combined with an alarming trend of population decrease, previously studied and analysed (CRP 2013; Carta et al. 2013; Bottazzi et al. 2006). According to the SDM index, State of Demographic Malaise, ${ }^{1}$ elaborated by Puggioni (2016), 31 municipalities in Sardinia are at risk of disappearing within the next 60 years. It is of particular interest to consider the dynamics of the population in Sardinia in the last 25 years (1991-2016), and compare what happened in the Coastal Municipalities (CM), where the tourism flow is relevant, to the Inland Municipalities (IM) (Table 1). Bottazzi (2015) defines the demographic process in Sardinia as a kind of 'doughnut' depopulation. Indeed, data show how the inhabitants are gradually abandoning the core of the region (Fig. 2). We can briefly analyse the data. Even though the population density was definitely lower in IM than in CM (110.6 people $/ \mathrm{km}^{2}$ and 49.6 people $\left./ \mathrm{km}^{2}\right)$, in 1991 there was a balance between population in CM and IM. Looking at the 2016 data, a decrease of population emerges (-3.3\% in IM), on the contrary, in CM the population increased by $4.5 \%$. Then, if we divide municipalities in Inner Areas or Centres and in Small Municipalities

\footnotetext{
${ }^{1}$ This indicator was obtained by combining 7 factors, such as variation of population in the 1951-2011 period, index of the elderly, etc. They are considered relevant to understand the state of the demography of each municipality.
} 


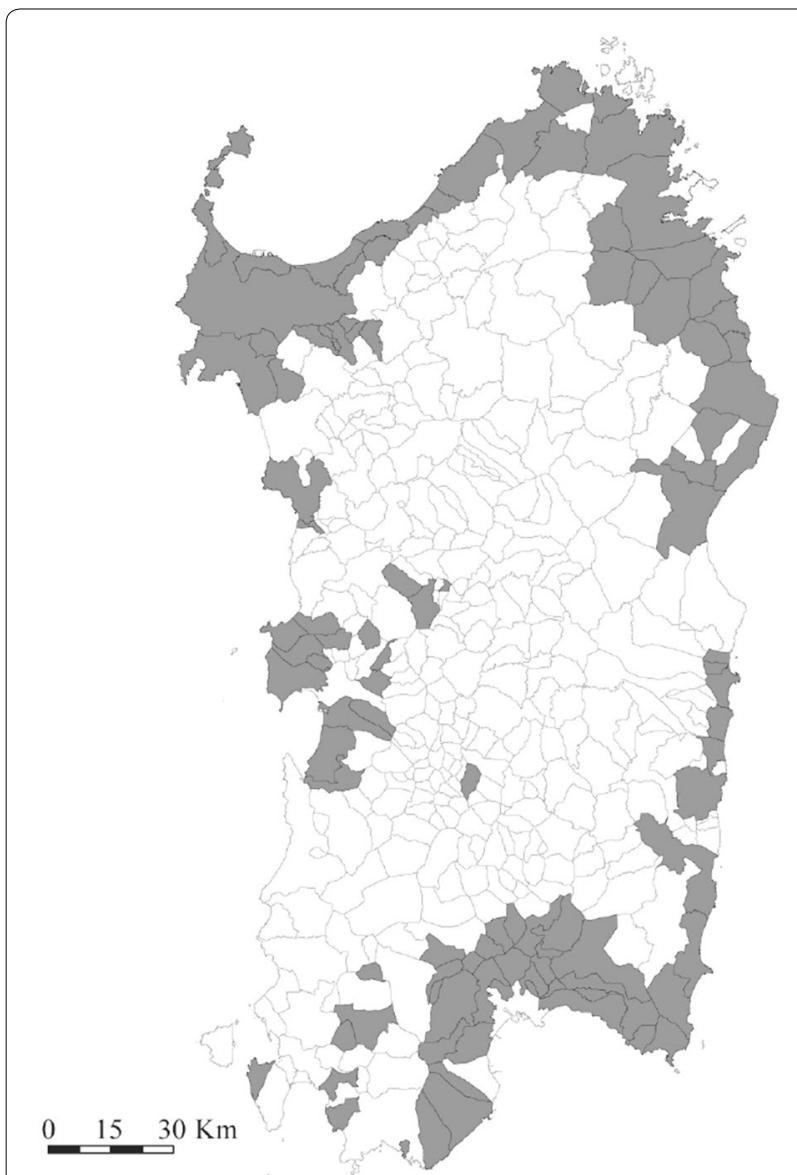

Fig. 2 Map of municipalities (in grey) with an increase of population in the period 1991-2016. The others have a decrease of population (Source: Elaboration from Istat data)

(less than 5000 inhabitants) and no Small Municipalities (more than 5000 inhabitants), data shows that population increases in the centres and in municipalities with more than 5000 inhabitants; on the contrary, population decreases in Inner Areas and in Small Municipalities. We can notice that Inner Areas and Small Municipalities present a different behaviour if they are CM or IM. Indeed, even taking categories affected by a rate of depopulation, $\mathrm{CM}$ presents an increase of inhabitants, with peaks of $+15.2 \%$ for CM classified as Inner Areas.

This confirms the national data: at present, $66.37 \%$ of Italy's population lives in the plains and coastal areas, whilst the inland areas (about $64 \%$ of the national territory) is scattered with $33.63 \%$ of the population (Istat 2009).

The tourist sector in Sardinia is quite an important economic sector (ISTAT 2017). From 2004 to 2015, the tourist arrivals increased by more than 33\% (SRM 2016). It is significant to highlight that, according to 2016 data (Istat 2016), 50\% of the total amount of the arrivals on the

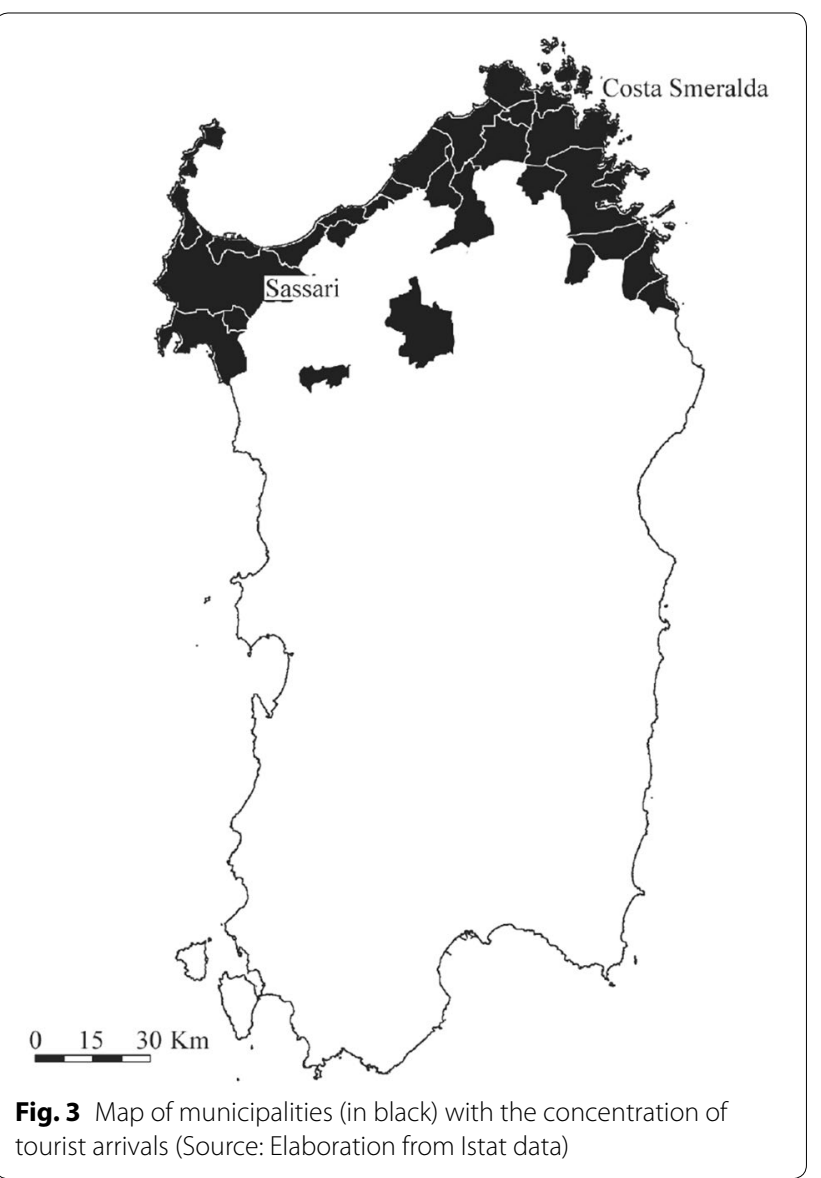

Island was in the North of Sardinia (Fig. 3). This tourist flow is strictly along the coast, so much that on approximately 1,400,000 arrivals, $93 \%$ are in coastal municipalities, and just $7 \%$ in inner ones. Cannaos and Onni (2017) have addressed an interesting consideration on the increase of tourism in the coastal areas in Sardinia and a parallel decrease of population in inner parts of the Island.

\section{The strategy (part I): rethinking that which already exists:} the historical railway of Trenino Verde

Inner areas of Sardinia are crossed by historical railway lines, called Trenino Verde (Little Green Train), still active in spring and summer months as slow tourist lines. '...So we will go by the secondary railway, wherever it goes.' Says D.H. Lawrence in his novel 'Sea and Sardinia, written in 1921. He tells of his journey on the Trenino Verde ante litteram. These were secondary railways which had the purpose of connecting the inland agro-pastoral areas with the mining areas (very important to the Island's economy at that time), and with the ports. The infrastructure was designed according to the wishes of the Count of Cavour and inaugurated after his 


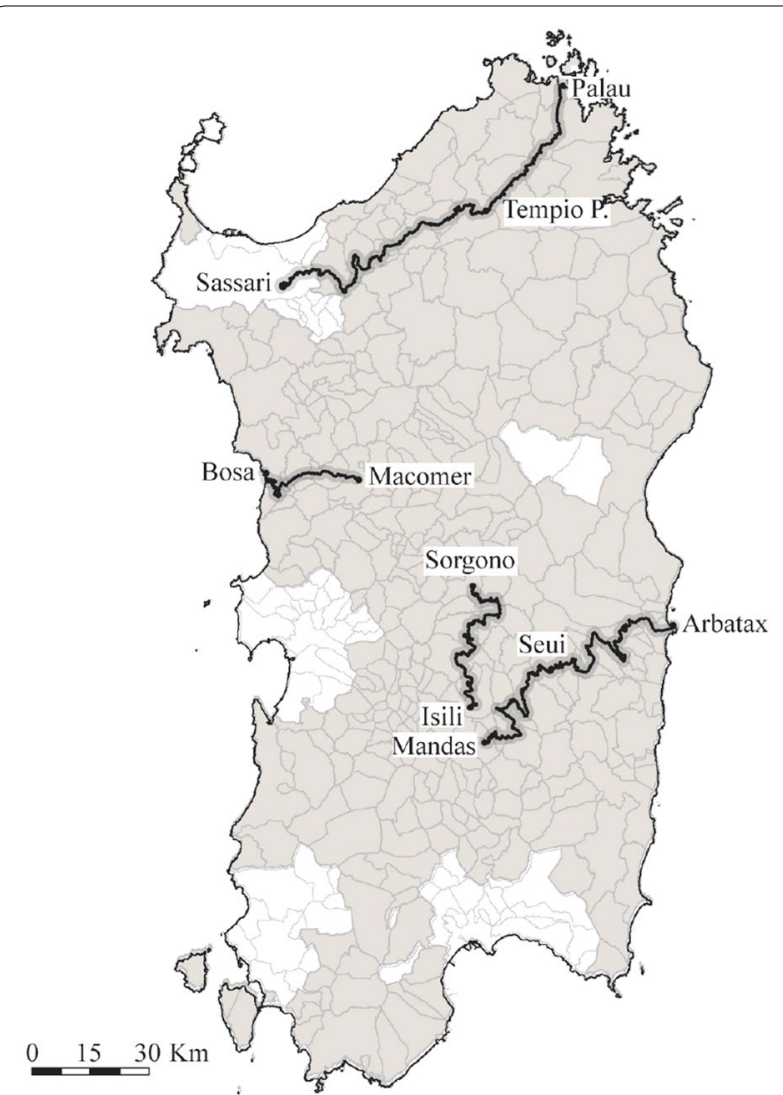

Fig. 4 Map of historical railways, Trenino Verde (in black). In grey, the municipalities classified "inner areas" (Source: Tracks from http://www. treninoverde.com/)

death in 1893. Originally, the length of the Island's secondary railway was approximately $1000 \mathrm{~km}$, making it the longest narrow-gauge railway in Europe (Pilia 1994). In the 1970s, after many years of service, the Italian railways underwent major reduction and for this reason, private entrepreneurs-who had understood that investment in this sector was no longer profitable-stopped investing. As a result, State intervention was deemed necessary and the outcome was a reduction of the railway to approximately $600 \mathrm{~km}$. In time, the risk of total abandonment of the railway increased. Local communities, and above all the railway workers, brought back memories of the English author's work when, in 1997, the 'Trenino Verde della Sardegna' was suggested. Trenino Verde lines were converted into tourist railways. These are 'lines dedicated exclusively to tourism that does not provide public service' (Blancheton and Marchi 2012, 33).

In Sardinia, the historical railway was divided into four sections distributed around the island each used for tourist purposes: (1) Sassari-Tempio-Palau $151 \mathrm{~km}$; (2) Macomer-Bosa 46 km; (3) Isili-Sorgono 96 km; (4) Mandas-Seui-Arbatax $134 \mathrm{~km}$ (Fig. 4). This operation

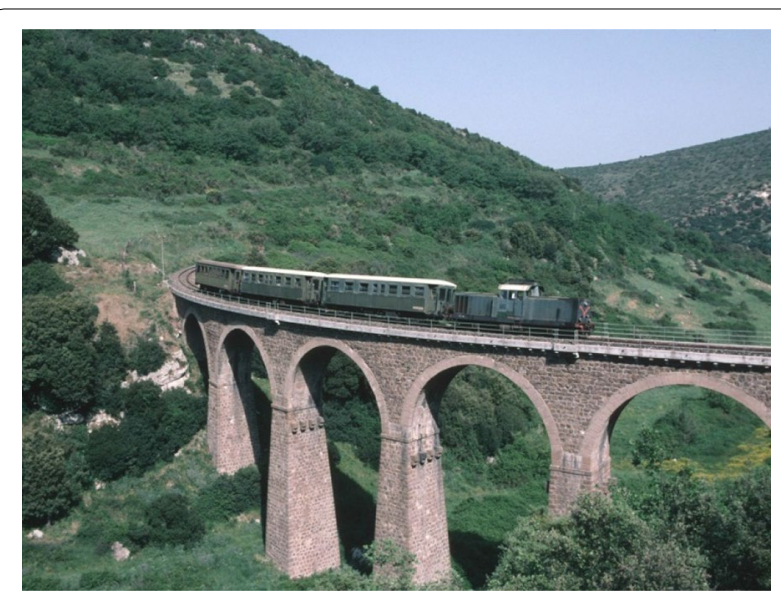

Fig. 5 The Trenino Verde (Source: Photo from http://www.treninover de.com/)

has been rather successful, so much so that this tourist railway is still active after 20 years. The main attraction of this train journey is the landscape, a sight in the distance which is observed from the window. The value of these places is mildly perceived during the journey but may not easily be fully appreciated as the Trenino does not stop but for the odd short 'photo-breaks.' That which today encourages tourists to venture into inland Sardinia on the Trenino Verde is curiosity and the hope of getting to know the true essence of the Island away from the coast (Fig. 5). The present experience offered meets these wishes only in part and the tourist experiences it inactively; they may admire the inspiring landscape but hardly get to see the villages of which they catch glimpses on the way. Considering this as a waste of potential, the proposed project is based on a mixed conception of mobility that tries to associate train travel with cycling as it has the positive effect of experiencing places in a sustainable way.

\section{The strategy (part II): combining railway tourist lines and cycle tourist paths}

This research studies how slow tourism, representing an alternative to the usual tourism on the coasts, may activate a regeneration of Sardinian inner areas. If the Trenino Verde were to stop in the smaller towns and were supported by efficient mobility facilities such as buses, bicycles and adequate pedestrian and cycle paths that connect the stations to the centre of the villages, this would allow for a comprehensive experience of the territory. Not only to experience the natural scenery but also to appreciate the value of its cultural heritage. The Trenino Verde and its stations can become gateways of the territory (Moscarelli et al. 2017), allowing tourists to 
discover inland Sardinia. The basic element of this project is to provide the missing link in bicycle tourism: the Trenino Verde can surmount the complicated slopes that characterize Sardinian territory. Taking advantage of the Trenino Verde, cyclists would be able to move from coastal to inland territory, stop at any station and create their own travelling experience.

By common definition, bicycle tourism is a cycling free-time activity whereby at least $24 \mathrm{~h}$ are spent away from home (Ritchie 1998). This means there may be various kinds of cycle tourists, such as mountain bikers, holiday cyclists, experienced and inexperienced cyclists or group-led cycle touring (Hoyt and Lumsdon 1993): bicycle tourism has a wide variety of individuals and potential market segments. Legambiente and ISNART (National Institute of Touristic Research) have issued some impressive and encouraging data on the presence of cycle tourists in Italy: in 2018 8.4\% of the entire Italian tourist flow has been identified as cycle tourism and cycle tourists have spent over 77 million days on specific itineraries and destinations. Dividing the presence of tourists by the average number of nights spent travelling, the result is that over 6 million people have embarked on this kind of 'active vacation' confirming an increasing presence of cycle tourists by $41 \%$ in the $2013-2018$ period (ISNART and Legambiente 2019).

It is important to highlight that cycle tourism has a non-competitive nature, and is an activity suitable for all ages, ability and training. Thus, the safety of the roads is a priority in planning cycle tourism infrastructures: long distance (more than $150 \mathrm{~km}$ ), paths need to be created independently and not as shared routes (ADFC 2017; AA. VV. 2009). In European Countries, such as Germany, Denmark or the Netherlands, where cycling routes were designed with this criterion, bicycle travellers are able to move around within the territory. This allows for regeneration of those areas from different points of view. Firstly, from an economic perspective.

'These travellers contribute to the local economy by stimulating the development of infrastructure construction (e.g. roads, bicycle hire/repair shops, and accommodation). Meanwhile, the development of the service sector (e.g. food and beverage service) [...] provides business and job opportunities.' (Han et al. 2017, 293).

The economic impact of cycle tourism in different sectors, related both with the so-called bike economy and with the consumption of local products and services, is largely recognised (AA. VV. 2014; Cope et al. 1998; CC 1995). According to the National Tourism Observatory (ENIT), the daily average expense of a cycle tourist amounts to 65.8 Euros, plus 54.6 Euros per day for accommodation and 255.4 Euros for the journey. Typically, cycle tourists have medium to high standards regarding levels of comfort and their choice in accommodation is at least in the 3-star bracket, making this a highly demanding and quality-orientated kind of tourist (ENIT 2016).

Secondly, cycle tourism can foster social regeneration. Indeed, by riding through places and activating a demand for services, local communities are animated (Dickinson and Lumsdon 2010). Thirdly, this kind of tourism can promote a cultural reactivation. This slow passing through different landscapes and villages gives the scenery a narrative and representative connotation (Pileri et al. 2015), showing its heritage of parks, natural reserves, historical settlements, cultural assets, museums, local traditions, etc.

\section{Development of the project}

The project has been elaborated by establishing fundamental guidelines, acknowledging common grounds for the various areas and developing different strategies for each case. Main recurring elements of the project are:

(1) Reopening of stations along the historical railway, the Trenino Verde Most stations are within reach of the small urban centres but do not benefit at all from the potential advantages that could be gained from the crossing of the Trenino Verde. The reopening of stations and consequently the stops in between would mean that the tourist would be able to experience not only that which may be perceived from a train window but would also have the opportunity to alight and truly experience the identity of these places. The station itself creates the need for services which in turn mean employment opportunities, therefore, the reopening of the stations would involve only those within the villages and strategically involved in the cycle-tourist paths. The continuity between train and bicycle guarantees a complete and fluent itinerary for the tourist. The fundamental concept of connecting is most significant as the stations provide links to other means of transport (which of course would need to coincide with train arrival times) and, above all, become start and arrival points for cycle routes.

(2) Designing new cycling routes The role of cycle tourism highlights the idea of reconnecting isolated inner areas with bigger cities and the coastline. It is for this reason that interventions propose cycle tracks which link inland towns to the coast, smaller towns to cities and between intermodal terminals. The routes have been designed following three fundamental criteria. (a) Beauty, meaning the variety of 
the landscape and the crossing of places of interest such as historical settlements, churches, archaeological and natural sites. (b) Tourist flow, connecting the Trenino Verde stations with the regional railway and with the seaside. (c) Safety: if cycle tourism is to be considered for everyone, that is to say, people of all ages and abilities, then safe roads are imperative. Cycling in safety is the first and most essential objective for the cycle traveller and the presence of dedicated infrastructures is a deciding factor when choosing a travel destination.

(3) Designing with the method of the field trip The masterplan design of the routes was based on a study of minor roads, especially those between plots of land. In order to plan an infrastructure efficiently, it is important to survey and acquire knowledge of the areas concerned. This allows the production designer to identify himself with the user and avoid giving 'top-down' solutions which could possibly prove to be a hindrance. In particular, as far as the bicycle is concerned, the main problem is related to slants and slopes. The survey carried out made it possible to avoid routes which have very steep slopes and study alternative routes that do not exceed a gradient of $5 \%$ for a maximum of two kilometres. Another distinguishing feature in this project is the beauty of the areas through which one travels: special attention has been given to routes through farmed fields, grazing land and woodland. In some cases, farms have deliberately been included in order to promote direct knowledge of farming and yielding of local products. Due to lack of alternatives, an overlap of the route with provincial roads has occasionally been considered obligatory. This implies that in order to guarantee the same criteria in terms of simplicity and safety, placement of cycling routes on existing roads would be required.

\section{Results}

The research experiments such strategy taking into account only one of the Trenino Verde routes: Sassari to the Port of Palau, through Tempio-Pausania (see Fig. 4), $150 \mathrm{~km}$ in approximately $3 \mathrm{~h}$.

\section{The study area analysis}

The route Sassari-Tempio-Palau is the longest. This section of the network goes through and links the two historical regions of Gallura and Logudoro. Passing through the Anglona plain, Mount Limbara and Coghinas Lake, the Trenino Verde travels at slow speed and crosses small remote villages. Besides the natural beauty, these areas have a historical and cultural heritage: unique nuragic age archaeological sites, ancient religious architecture, registered quality food and wine (DOC, DOP and DOCG trademarks), handcrafted textiles and ceramics decorated with ancient symbols, to name but a few (Fig. 6).

Said route goes through twenty-four villages where the train stations are closed and often derelict. Only three stations are active: Palau and Sassari, at the start and end of the line, respectively, and an intermediate stop in the station of Tempio-Pausania, the provincial capital.

The most densely populated towns along the line of the Trenino Verde are Sassari (127,634 inhabitants), TempioPausania (14,172 inhabitants) and Arzachena (13,633 inhabitants). The least populated are Laerru (933 inhabitants), Bortigiadas (767 inhabitants) and Martis (536 inhabitants) (Fig. 7).

\section{The design of new cycle paths}

According to said factors and criteria, different projects could be applied to the case. The following three cycle routes are exemplify the possibility to apply analogous solutions in similar areas. These three options articulate different kinds of links and ways in which to enter and discover inner areas: (1) link between inner and coastal areas; (2) link between a small village, classified as inner area, and a bigger town with mobility facilities and services, classified as pole; (3) link between the Trenino Verde line and the national active railway, using the abandoned path of an old railway line (Fig. 8).

The first, approximately $60 \mathrm{~km}$, has the purpose of connecting two stations of the Trenino Verde line and to generate a 'ring' linking them to other two tourist towns by the sea (Castelsardo and Valledoria). This path resembles that given in the 'Guide to Cycle tourism in Sardinia' for the same area-it is the only one to have a largely flat itinerary. The aim of this cycle-tourist path is to steer coastal tourism flow towards inland Sardinia and reach the train stations. This would increase the number of tourists travelling through the countryside towards major towns and would also generate and encourage a kind of tourism that is aware of the quality that lies inland.

The second, approximately $13 \mathrm{~km}$, passes through the mountainous area of Bortigiadas, crossing the town and reaching Aggius, which is a charming village that is not crossed by the railway. The path descends towards Tempio Pausania where the Trenino Verde stops. This provides the possibility of the cycle path and train working together as an intermodality system in order to reach considerable altitudes and therefore meet as many users as possible.

The third path, approximately $24 \mathrm{~km}$, is the refurbishment and conversion into a cycle path of a railway fallen into disuse in the Sixties that represents the only link 


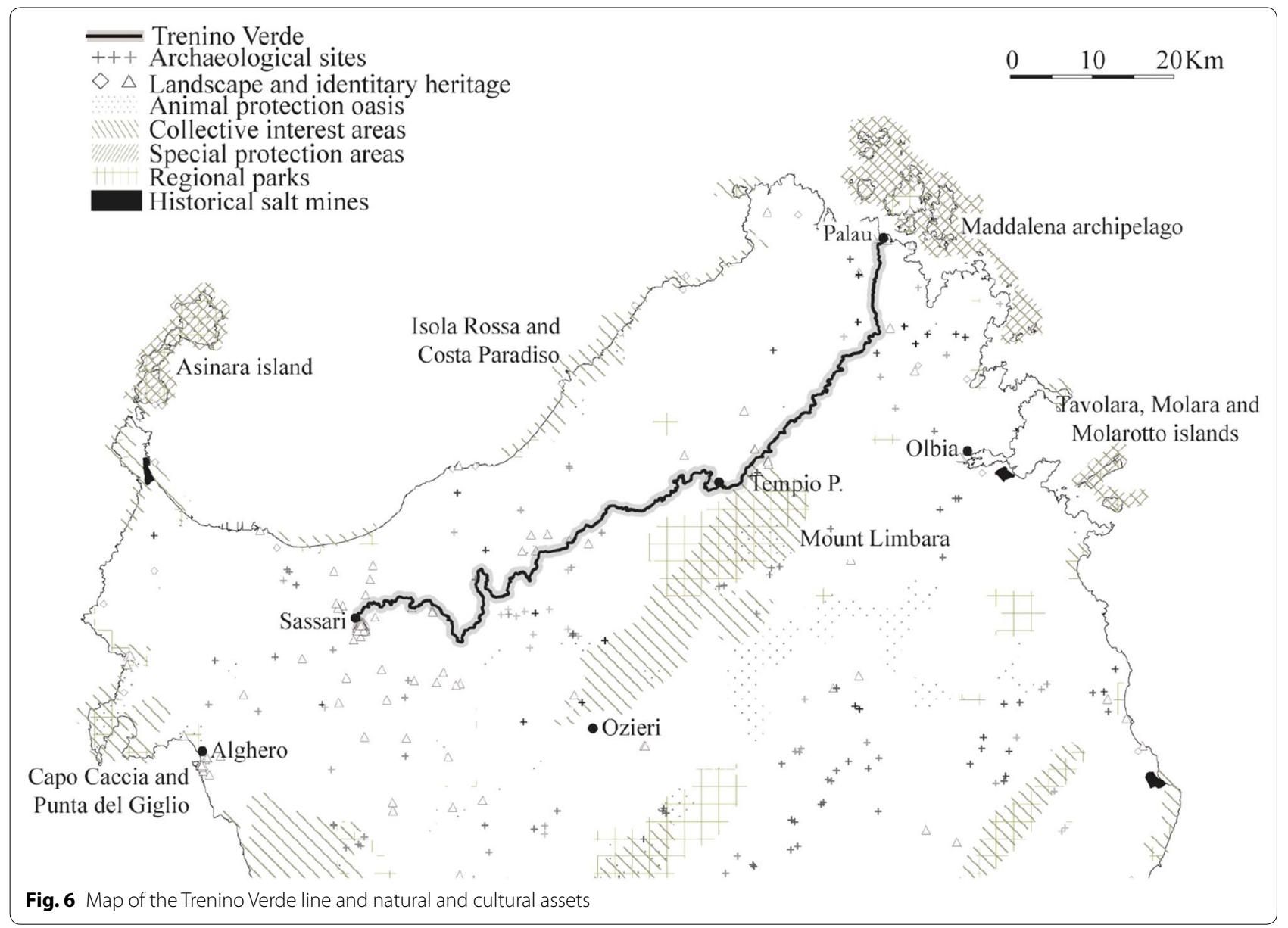

between the Trenino Verde railway and the national railway (Ferrovie dello Stato). This solution may prove to be convenient considering that it would take advantage of the existing track (although it is partially missing and abandoned): slopes and turns are gentle and therefore easy to ride. The link between Luras and the train station in Monti-Telti (through Calangianus) would guarantee a uninterrupted service of intermodality and the possibility to transform this into a tourist area.

These paths are approximately $93 \mathrm{~km}$ long, and more than $75 \%$ are already suitable for this purpose since they are cycle roads or minor roads, between plots of land. Each proposal has been developed differently: morphology, distance from major centres or regional railway lines, existing roads and paths and the presence of places of interest have been a few of the elements that have influenced the planning process. Moreover, developing more than one path enables tourists to decide and build their own experiences of the territory (Fig. 9).

The feasibility of these different projects has to be briefly covered. On one hand, it is interesting to imagine a gradual creation of the project, starting from a pilot path in order to experiment the idea. After which the other two paths may be completed at a later date. On the other hand, there are public participants, also thanks to some specific policies, that can finance this kind of project. First, the Italian Government provides funds for the municipalities classified as "inner areas". In addition to that, the Sardinia Region is financing an interesting and ambitious plan to create a cycle tourism network. Finally, Fondazione FS Italiane, which manages most of the historical railways in Italy, may finance and foster the regeneration and enhancement of the Trenino Verde in Sardinia.

\section{Discussion and conclusions}

Sardinia, likewise many Italian and European regions, is suffering from the phenomena of marginalisation, especially in its inner areas affected by depopulation and abandonment of towns in favour of coastal cities. Taking into account the tourist sector data, a relevant imbalance between inner and coastal municipalities emerges. Traditional 'summer tourism' has generated an exploitation in the use of resources, emphasizing the disparities 


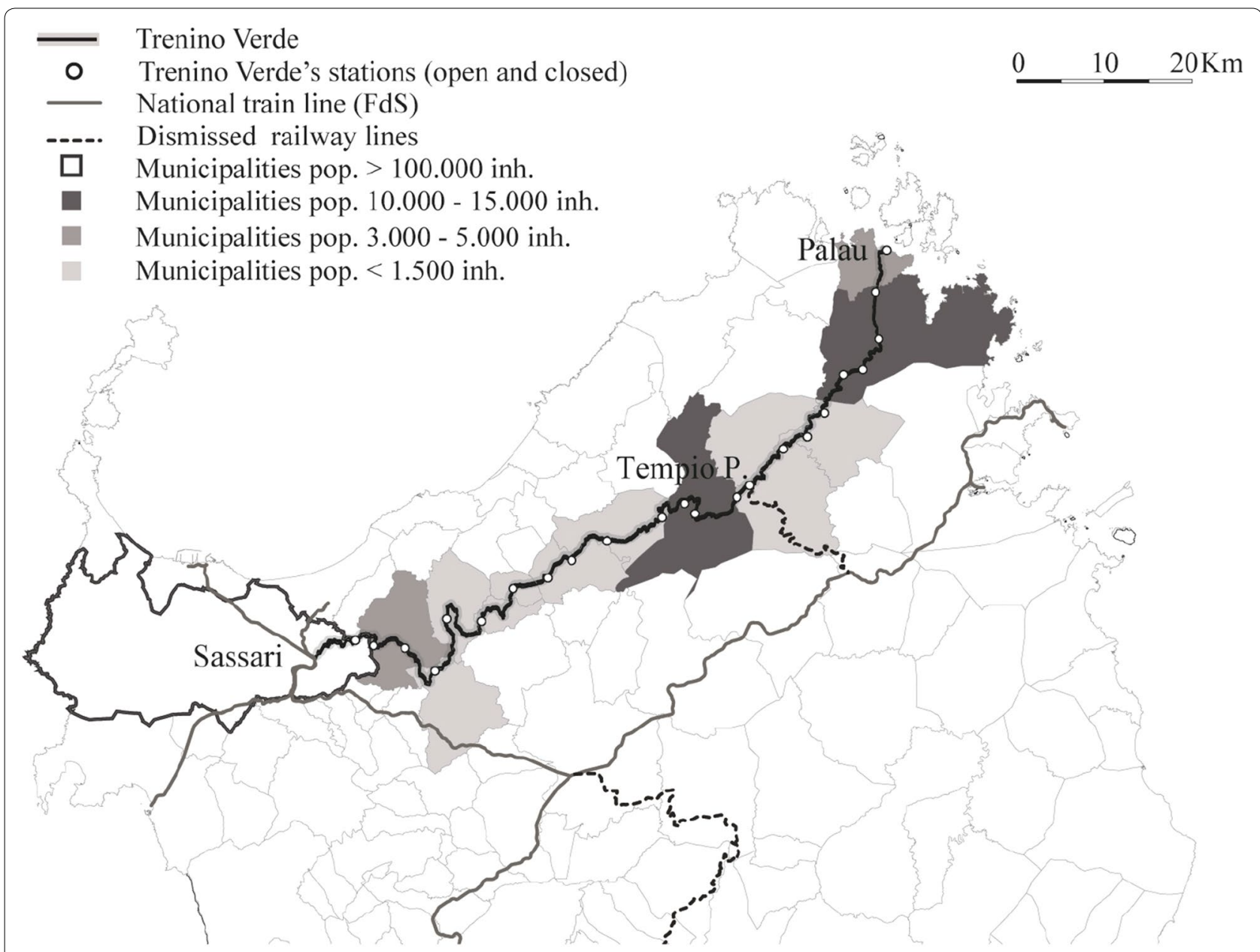

Fig. 7 Map of municipalities along the Trenino Verde line and intersection with national train line

between Inland Sardinia and Coastal Sardinia. Since Italian National Strategy suggests tourism to regenerate inner areas, in this research it is experimented how this can be applied to this case. The study proposes a slow and sustainable alternative to intensive coastal tourism. The main idea is to combine a pre-existing historical railway with a new well-planned and safe system of cycle-tourist paths. Both cycle tourism (Lumsdon and McGrath 2011; Lumsdon 2000) and rail tourism (Kosters 1992; Dann 1994; Hall 2005; Novelli and Benson 2005) are regarded as branches of sustainable tourism.

These two slow infrastructures can innervate inner territories of North Sardinia thanks to multiple actions: (1) by connecting coasts to inner municipalities; (2) by allowing tourists to discover inland areas; (3) by generating a network together with the active state railway.

A slow train line and cycle tourism paths, due to their uniqueness in passing slowly through the territory, could activate an economic, social and cultural regeneration. Such tourism, supported by adequate facilities and infrastructures, would have the potential to create a green economy and green jobs, which would become the driving force for new extended, sustainable and lasting economies in those marginalised areas. The economic outcome is merely one of a series of considerable effects, which would have consequences on the areas of interest as well as on those who live in them and who seek new perspectives following the crisis. This type of tourism creates the demand for overnight accommodation, food and catering services, rail and bicycle maintenance services. In addition, the cultural discovery of the places would give the opportunity to villages to offer the tourist an unforgettable experience. There would be employment opportunities not only in the tourism sector but also in many secondary activities, related to the territorial capital still present there.

This research has the intent to demonstrate that it is possible to consider tourism as a regeneration trigger. In the case of peripheral territories, far from main infrastructures and services, the state of isolation can 


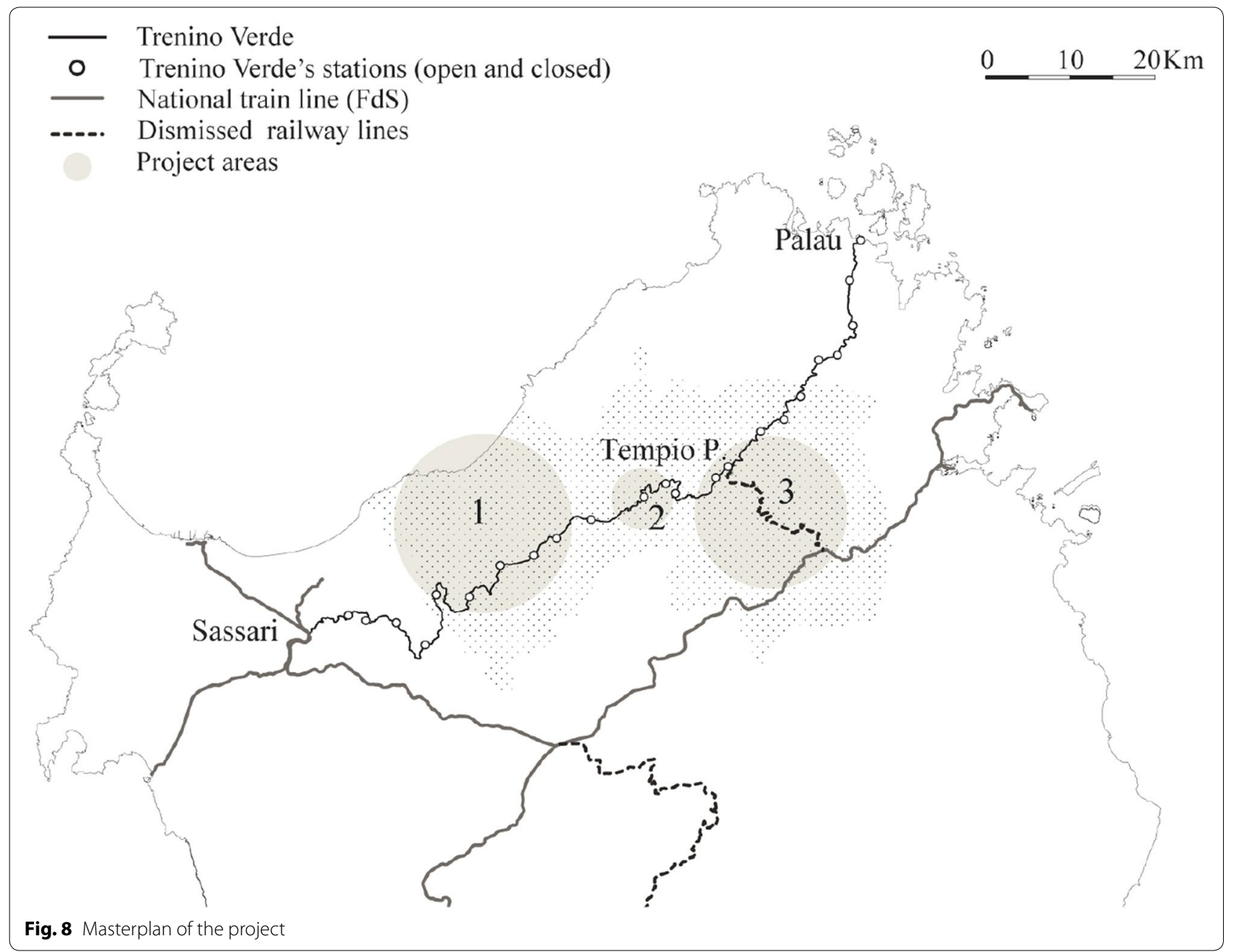

become the positive aspect to enhance. In the case of marginalised areas, it is necessary to elaborate innovative paradigms, alternative to ones used in other territories. Concerning the issue of tourism, this means that we need to find new proposals to discover and experiment the uniqueness of such regions, which still possess a strong natural, historical and social capital.

In conclusion, it is possible reach three main considerations. (1) This kind of project is feasible also in other situations, not only in Sardinia in connection with the other Trenino Verde lines, but also on mainland Italy, especially in those contexts with similar characteristics. (2) One of the most relevant aspects is that slow tourism and thereby the discovery of the territory generates economic income distributed in local places and communities. Tourism, when strictly related to the territory as in the case of slow tourism, may aid the recovery of marginalised places, such as Italian inner areas. A slow tourist flow can generate an economic, cultural and social re-activation by introducing the need for accommodation facilities, food and leisure activities, the wish to discover the territory and its heritage. Moreover, it would reduce isolation of the population and enhance human capital and traditional know-how. The initial investment would be considerably low since several elements of the project are already present in the territory. (3) Promoting territorial projects enhances the possibility of cooperation between municipalities. Indeed, 


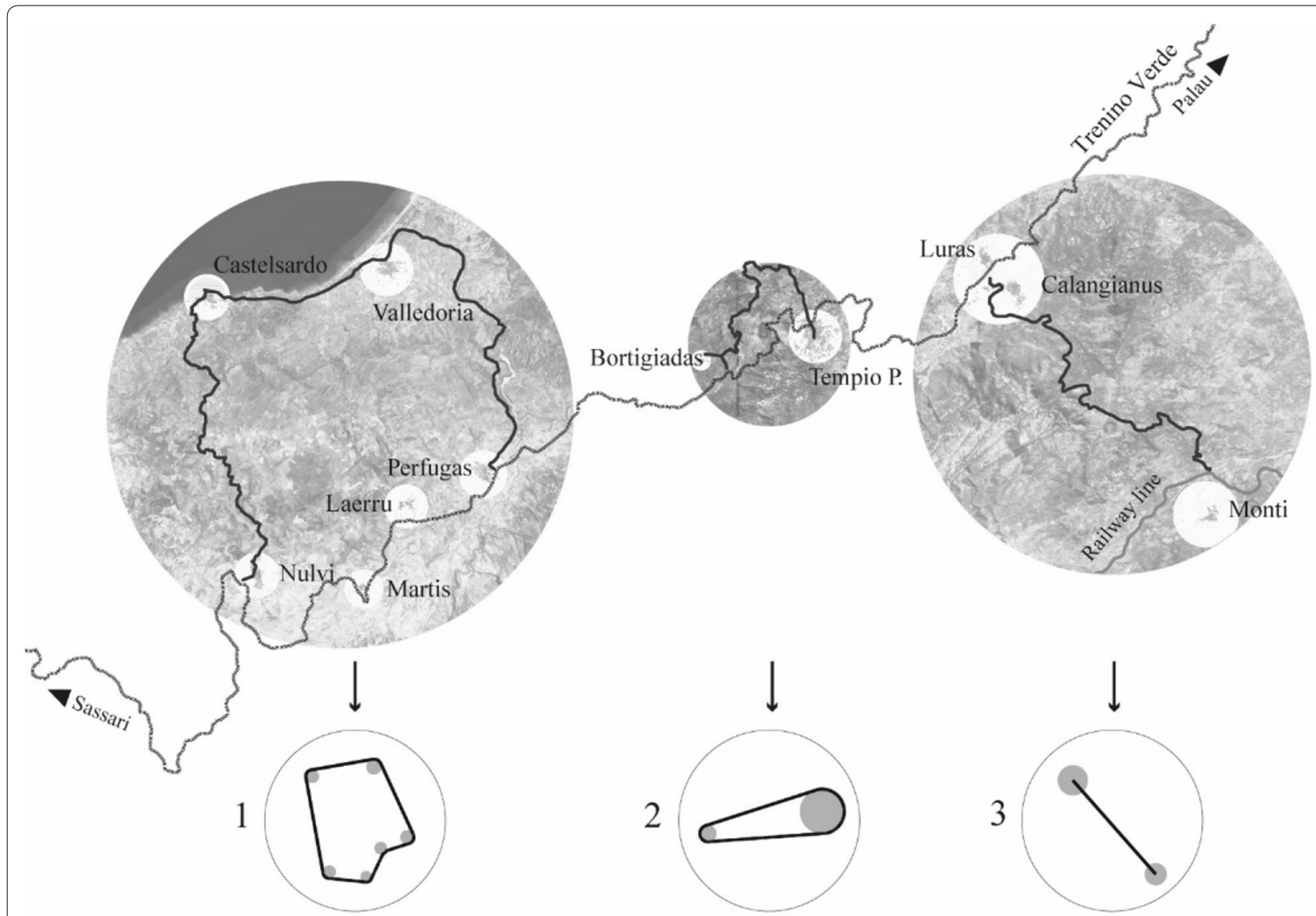

Fig. 9 Plan of the new cycle tourist paths in relation with the Trenino Verde line

the smaller and more isolated these municipalities are, the more they have to be able to interact beyond administrative fragmentation.

\section{Acknowledgements}

Nothing to declare.

\section{Authors' contributions}

First author carried out the research and wrote the results and discussion. Second author supervised the research and wrote the introduction and the methods. The third author supervised the research, with relevant contributions to conception and design of the project and the article, revising it critically for the content. All authors wrote the conclusion. All authors read and approved the final manuscript.

\section{Funding}

Nothing to declare.

\section{Availability of data and materials}

The data that support the findings of this study are openly available in Istat database, reference numbers Istat $(2009,2016,2017)$ and in the CRP database, reference number CRP (2013).

\section{Ethics approval and consent to participate}

Not applicable.

\section{Consent for publication}

Not applicable.
Competing interests

The authors declare that they have no competing interests.

Received: 8 July 2019 Accepted: 18 November 2019

Published online: 22 February 2020

\section{References}

AA. W (2009) Grundlagenuntersuchung Fahrradtourismus in Deutschland. Bundesministerium für Wirtschaft und Technologie (BMWi)

AA. WV (2014) Unlocking new opportunities: jobs in green and healthy transport 26. http://www.euro.who.int/en/publications/abstracts/unloc king-new-opportunities-jobs-in-green-and-healthy-transport

ADFC (2017) Travelbike bicycle travel analysis. https://www.adfc.de/fileadmin/ user_upload/Expertenbereich/Touristik_und_Hotellerie/Radreiseanalyse /Downloads/ADFC_Bicycle_Travel_Analysis_2017_engl._fact_sheet .pdf

Anci, Ifel (2015) Atlante dei piccoli comuni. https://www.fondazioneifel.it/ documenti-e-pubblicazioni/item/download/274_77d47e09ac29825 $7 b 458 d 3 e 5 f 05 b 26 e 1$

Barca F (2009) An agenda for a reformed cohesion policy: a place-based approach to meeting European Union challenges and expectations, independent report, prepared at the request of the European commissioner for regional policy. European Commission, Brussels

Bayona J, Gil-Alonso F (2012) Is Foreign Immigration the Solutionto Rural Depopulation? The Caseof Catalonia (1996-2009). Sociol Ruralis 53(1):26-51 
Bender O, Kanitscheider S (2012) New immigration into the European Alps: emerging research issues. Mountain Res Develop (MRD) 32(2):235-241

Blancheton B, Marchi JJ (2012) The three systems of rail tourism: French case. Tourism Manag Perspect 5:31-40

Bottazzi G (2015) Variabili demografiche e sviluppo locale. Considerazioni sullo spopolamento in Sardegna. In: Meloni B (ed) Aree interne e progetti d'area. Rosenberg \& Sellier, Turin

Bottazzi G, Puggioni G, Zedda M (2006) Dinamiche e tendenze dello spopolamento in Sardegna. Cagliari, Centro Regionale di Programmazione (CRP)

Breman B, Vihinen H, Tapio-Biström ML, Pinto Correia MT (2010) Meeting the challenge of marginalisation process at the periphery of Europe. Public Admin 88(2):364-380

Brouwer F, Baldock D, Godeschalk F, Beaufoy G (1997) Marginalisation of agricultural land in Europe. In: Conference paper Naplio, Greece

Cannaos C, Onni G (2017) Sardegna: ad marginem. Arch Studi Urbani Region 118:27-48

Carta V, Lobina E, Muscas F (2013) Dinamiche e tendenze dello spopolamento in Sardegna. Focus sulle aree LEADER. Un aggiornamento funzionale alle politiche di sviluppo rurale dell'Autorità di Gestione del Programma di Sviluppo Rurale della Regione Sardegna. http://www.regione.sardegna.it/ documenti/1_26_20101116090620.pdf

CC (Countryside Commission) (1995) The market for recreational cycling in the countryside. Cheltenham

Cope M, Doxford D, Hill T (1998) Monitoring tourism on the UK's first longdistance cycle route. J Sustain Tourism 6(3):210-223

CRP (2013) Comuni in estinzione. Gli scenari dello spopolamento in Sardegna. http://www.sardegnaprogrammazione.it/documenti/35_84_2014012009 1324.pdf

Dann G (1994) Travel by train: keeping nostalgia on track. In: Seaton A (ed) Tourism: state of the art. Wiley, Chichester

Danson M, De Souza P (2012) Regional development in Northern Europe: peripherality, marginality and border issues. Routledge, Abingdon

Di Biase C (2013) Small towns in inland areas: shared landscapes. In: Conservation-reconstruction. In: Crisan R, Fiorani D, Kealy L, Musso SF, eds. Small historic centers conservation in the midst of change. pp 131-139

Dickinson JE, Lumsdon L (2010) Slow travel and tourism. Earthscan, Washington

Domansky B, Lung Y (2009) Editorial: the changing face of the European periphery in the automotive industry. Eur Urban Region Stud 16:5-10

EC (2011) Cohesion policy 2014-2020. Investing in Europe's regions. Panorama. Inforegio, n. 40. http://ec.europa.eu/regional_policy/sources/docge ner/panorama/pdf/mag40/mag40_en.pdf

ENIT (2016) II mercato del cicloturismo in Europa. Politiche, and amenti e prospective. https://www.federciclismo.it/it/infopage/cicloturismo-andam enti-e-prospettive-in-europa-secondo-enit/7 debbeda-4dbb-4504-8a73$4 \mathrm{~d} 22265 \mathrm{dbf08/}$

Espon (2017a) PROFECY — Inner Peripheries: National territories facing challenges of access to basic services of general interest. https://www.espon .eu/programme/projects/espon-2020/applied-research/inner-peripherie s-national-territories-facing

Espon (2017b) Policy Brief: shrinking rural regions in Europe. Towards smart and innovative approaches to regional development challenges in depopulating rural regions. https://www.espon.eu/rural-shrinking

Eurostat (2016) Urban Europe-statistics on cities, towns and suburbs-patterns of urban and city developments - statistics explained. http:// ec.europa.eu/eurostat/statistics-explained/index.php/Urban_Europ e_\%E2\%80\%94_statistics_on_cities,_towns_and_suburbs_\%E2\%80\%94_ patterns_of_urban_and_city_developments

Fratesi U, Perucca G (2017) Territorial capital and the resilience of European regions. Ann Reg Sci 60(2):241-264

Garrod B, Wornell R, Youell R (2005) Re-conceptualising rural resources as countryside capital: the case of rural tourism. J Rural Stud 22:117-128

Hall D (2005) Transport tourism—travelling through heritage and contemporary recreation. In: Novelli M (ed) Niche tourism-contemporary issues, trends and cases. Elsevier, Oxford

Han H, Meng B, Kim W (2017) Emerging bicycle tourism and the theory of planned behavior. J Sustain Tourism. 25(2):292-309

Hoyt S, Lumsdon L (1993) Cycle opportunities. Simon Holt Marketing, Manchester

Ifel (2015) I Comuni della strategia nazionale aree interne
Ismart, Legambiente (2019) Cicloturismo e cicloturismi in Italia. http://mybik eway.it/wp-content/uploads/2019/03/1\%C2\%B0-rapporto-sul-Cicloturis mo-in-Italia-2019-Unioncamere-Legambiente.pdf

Istat (2009) Annuario statistico della popolazione italiana. Roma. https://www. istat.it/it/files/2016/12/Asi-2016.pdf

Istat (2016) Capacità degli esercizi ricettivi. Movimento dei clienti negli esercizi ricettivi. http://www.sardegnastatistiche.it/argomenti/turismo/

Istat (2017) Movimento turistico in Italia. Anno 2016. Roma. https://www.istat it/it/archivio/205128

Kosters MJ (1992) Tourism by train: its role in alternative tourism. In: Smith VL, Eadington WR (eds) Tourism alternatives: Potential and problems in the development of tourism. University of Pennsylvania Press, Philadelphia, pp 180-193

Liu J, Nijkamp P, Derong L (2017) Urban-rural imbalance and tourism-led growth in China. Ann Tourism Res 64:24-36

Lucatelli S (2015) Italian national strategy, acknowledging internal areas. Territorio $74: 80-86$

Lumsdon L (2000) Transport and tourism: cycle tourism—a model for sustainable development? J Sustain Tourism 8(5):361-377

Lumsdon ML, McGrath P (2011) Developing a conceptual framework for slow travel: a grounded theory approach. J Sustain Tourism 19(3):265-279

Maciocco G, Sanna G, Serreli S (eds) (2011) The urban potential of external territories. Franco Angeli, Milano

Maretti M, Salvatore R (2012) The link between sustainable tourism and local social development. A sociological reassessment. Sociologica, no. 2

Mazzola F, Lo Cascio I, Epifanio R, Di Giacomo G (2018) Territorial capital and growth over the Great Recession: a local analysis for Italy. Ann Reg Sci 60(2):411-441

Moscarelli R, Pileri P, Giacomel A (2017) Regenerating small and medium sized stations in Italian inland areas by the opportunity of the cycle tourism, as territorial infrastructure. City Territory Arch 4:13

Nordregio (2004) Mountain Areas in Europe: Analysis of mountain areas in EU member states, acceding and other European countries

Novelli M, Benson A (2005) Niche tourism—a way forward to sustainability? In: Novelli M (ed) Niche tourism—contemporary issues, trends and cases Elsevier, Oxford

OECD (2001) Territorial outlook 2001. Organization for Economic Cooperation and Development, Paris

Pileri P, Giacomel A, Giudici D (2015) VENTO. The gentle revolution cycling its way through the landscape. Corraini Edizioni, Mantova

Pilia F (1994) II trenino verde della Sardegna: un secolo di storia tra pionieri, banditi, letterati e turisti. Silvana

Pine BJ II, Gilmore JH (1999) The experience economy. Work is theatre \& every business a stage. Harvard Business School, Boston

Pinilla P, Ayuda MI, Sáez LA (2008) Rural depopulation and the migration turnaround in Mediterranean Western Europe: a case study of Aragon. J Rural Community Develop 3:1

Puggioni G (2016) Fenomeno dello spopolamento. In: Cocco F, Fenu N, Lecis Cocco-Ortu M (eds) Spop. Istantanea dello spopolamento in Sardegna. LetteraVentidue edizioni, Siracusa

Ritchie BW (1998) Bicycle tourism in the South Island of New Zealand: planning and management issues. Tourism Manag 19(6):567582

Romão J, Neuts B (2017) Territorial capital, smart tourism specialization and sustainable regional development: experiences from Europe. Habitat Int 68:64-74

Salvatore R, Chiodo E (2016) Aree interne e'tourism transition': nuove pratiche turistiche e riorganizzazione dell'offerta in funzione della rivitalizzazione. Agrireionieuropa 12:45

Serbanica C, Constantin DL (2017) Sustainable cities in central and eastern European countries. Moving towards smart specialization. Habitat Int 68:55-63

SRM (2016) II turismo in Sardegna. Le caratteristiche del settore. http://www. sr-m.it/wp-content/uploads/2016/10/Dati-Turismo-Sardegna.pdf

Turco A (ed) (1984) Regione e regionalizzazione. Franco Angeli, Milano

UVAL (2014) A strategy for inner areas in Italy: definition, objectives, tools and governance. Issue 31. Rome

\section{Publisher's Note}

Springer Nature remains neutral with regard to jurisdictional claims in published maps and institutional affiliations. 